\title{
5 In or out: sub-national island jurisdictions and the antechamber of para-diplomacy
}

\author{
Barry Bartmann
}

\section{THE SETTING}

When East Timor achieved sovereignty on 20 May 2002, the ceremony marked not only the end of an agonizing process of self-determination for the islanders of this small territory, but also arguably the final act of European decolonization itself. Yet was East Timor truly the last scraping of the bottom of the colonial barrel? There are various types of dependencies scattered across the oceans of the world, many of them islands, still subject to European metropoles. The quest for sovereignty, as the only acceptable path to self-determination, does not seem to be the burning issue in these few remaining territories. Many are content to maintain the security of metropolitan relationships into the distant future. Some, like Aruba, have actually considered and then rejected sovereignty as an appropriate future for the island. Most recently in Tokelau, with a population of 1500 , a referendum on independence failed to win the two-thirds majority required as the islanders elected to retain the continued financial security of their relationship with New Zealand (Chapman, 2006). In some cases, as in Mayotte, a relationship with a distant metropole is seen as a safer and more secure association than the possible alternative of dependence on a larger central government nearby.

Yet the recent efforts of Nevis to secede from neighbouring St Kitts are a dramatic example of continuing centrifugal forces at play in archipelago states (Premdas, 1998, ch. 2; Dee, 2001, ch. 5). Similarly the very small federation of the Comoros has been plagued by secessionist movements from the time of its independence, first with Mayotte, still in the colonial womb, and more recently with both Moheli and Anjouan (Rushby, 2001). Even in the Åland Islands there has been a dramatic growth in recent years of a pro-independence movement in public opinion at large, while two political parties unequivocally support sovereignty (Anckar, 2002, pp. 221-224).

The issue of sovereignty, then, is not entirely off the table, even in those small sub-national island jurisdictions where domestic debate seems to be preoccupied with other issues. It retains a powerful appeal for many Nevisians, it is a pressing ambition for many Kanaks of New Caledonia, and it commands persistent minority support in other French territories such as Guadeloupe and French Polynesia. It is the basis of a government-commissioned report in Bermuda. It continues to shape the constitutional debate in the Faeroe Islands and it remains a long-term vision or contingency plan in other island jurisdictions such as Greenland or the Isle of Man. It is a nostalgic fantasy for many Newfoundlanders as an expression of their frustration and discontent in the Canadian federation. Even in tiny Tokelau, 60\% 
of the islanders voted in favour of independence in spite of the economic risks (Chapman, 2006).

For the most part, however, the remaining small island sub-national jurisdictions live contentedly in legally dependent relationships which typically allow considerable autonomy and latitude, even in relations with the outside world beyond their metropolitan centre. Indeed, the capacity to engage the outside world through varying patterns of communication and representation, a phenomenon now widely termed 'para-diplomacy', is one of the developments inviting a reassessment of these small islands' once conventional constitutional future towards sovereignty. The circumstances of these small island territories and the current options open to them are themselves striking evidence of a rapidly changing international system.

Long-standing distinctions, both legal and diplomatic, between established sovereign states and other international actors seem to be increasingly blurred by changing practices in international relations and particularly by the activity of nonsovereign and unrecognized jurisdictions in external representation. These alternative practices of international relations may be seen metaphorically as an antechamber to the formal, legal and recognized diplomacy of the grand hall itself. Some entities may be able to leave the antechamber for the great hall for specific purposes (such as membership of intergovernmental organizations), but not for others (such as the accreditation of legations). Others, indeed most others, are confined to the antechamber. Sub-national island jurisdictions are among the less recognized players in conventional international relations texts; but many of them are now engaged in unexpected external relations, acquiring means to enhance their regional and even global presence. To be sure, the increasingly assertive external engagement of subnational jurisdictions is also evident among other international players: de facto states, often 'nations in waiting' (Bahcheli et al., 2004), regional organizations edging towards approximations of confederacy, even cities and metropolitan areas seeking to create transnational regions of economic activity with some measure of jurisdictional or institutional identity transcending the state borders which divide them. In short, the remaining 'remnants of empire', as well as small jurisdictions linked with a noncolonial metropolitan centre, are participating in a rapidly changing global milieu characterized by multiple levels of legal, political and diplomatic status and capacity. As conventional distinctions of status and prerogatives seem to be blurred, particularly between internationally active dependent territories and sovereign states, the phenomenon of para-diplomacy appears as both an agent and a consequence of that change. It is not surprising, then, that most of the current discussion in the literature is focused on jurisdictions below the sovereign state.

Michael Keating sees the emergence of para-diplomacy as an understandable response to powerful currents of change within the international system: globalization and the rise of transnational regimes. Both "have eroded the distinction between domestic and foreign affairs and by the same token have transformed the division of responsibilities between state and subnational governments" (Keating, 1999, p. 1). Globalization has expanded economic space beyond the reach of national governments, thus pulling sub-national jurisdictions on to the larger stage of economic interaction. Both cultural and political consequences follow as states find it ever more difficult to exploit their traditional role as guardians of national identity with the economic space around them drifting in every direction and new currents of activity, linking both local and global players. Similarly, in such a setting, 
transnational regimes have emerged to meet the challenges of flux in all directions, with many such regimes speaking directly to the core interests and central issues of sub-national jurisdictions.

Keating reminds us, however, that the consequences of these changing dynamics within the international system do not necessarily fatally erode the importance of territorial competence and particularly of territorial identity. Indeed, Keating speaks of "the reinvention of territory" as a distinguishing feature of the contemporary international system (Keating, 1996, pp. 47-48; see also Bartmann, 1998, pp. 239 250). Moreover, territorial fault lines within states, particularly multinational states, may be accentuated and, if anything, a resurgent localism appears to be an unexpected response to globalization (Bartmann, 2000). This may be particularly true in small island jurisdictions, where territorial identity is both inescapable and ever intrusive and where "the geographies of the mind" (Knight, 1982, p. 517) are so pronounced. The affirmation of sub-national territorial identity and jurisdictional competence can only induce the elaboration of para-diplomatic relationships and thus reinforce the blurring of distinctions of status and privilege that were once at the core of international diplomatic practice.

Para-diplomacy can be best understood as a field of international interaction apart from the conventional channels of international diplomacy. Within this field are many players with different objectives and, most important, different levels of sanction. They include sub-national jurisdictions which may pursue agendas that are broadly functional or highly political, that is, identity-reinforcing and even state-building in their objectives. Some, following the work of Ivo Duchacek (1986), have narrowly defined para-diplomacy as essentially "political-functional contacts with foreign countries... which are bound to have some political dimension" (Lubin, 2003/04, p. 22). In contrast to this perspective, proto-diplomacy "describes those international outreach activities of a non-central government like... Québec that tries to graft some sort of a strong autonomist or even sovereigntist message onto its economic, social and cultural links with foreign countries" (Lubin, 2003/04, p. 22). These distinctions are typically very difficult to dissect. Yet identity affirmation may not be a steppingstone to secession and the commitment to the latter can be muddied depending on the party in power or, more typically, on the vicissitudes of the governing coalition at the time. For our purposes in this article the term para-diplomacy refers to all those external activities by non-sovereign jurisdictions that stimulate and approximate the formal, legal and recognized diplomatic practices of sovereign states. Whatever the differences of purpose, all these sub-national players enjoy a latitude of international participation that was once far beyond their status, but which is now part of an expanding international network. But it is a network sanctioned by their metropolitan centres and consequently by the international system, itself still a system based on sovereign states.

It is a field which also includes a wide range of players without sanction, apart from a few patron states. These entities still attempt to participate in the same field as those which enjoy a recognized measure of legitimacy. For these territories, however, de facto states as opposed to sub-national jurisdictions, e.g. Northern Cyprus in contrast to the Faeroe Islands, the actual exercise of para-diplomacy is hugely different, although the cosmetics are similar. Engagement with sanction, however limited, will in the end determine the actual substantive relations of players in the field. 
Para-diplomacy, then, is a field of international activity which simulates or approximates official and conventional international relations. All the cases discussed in this paper are within this 'antechamber'. But some can simulate the conventions of official diplomacy more effectively than others and typically do so with the acquiescence of their metropolitan centres and therefore of international society as a whole. In these cases long-standing conventions of international diplomacy are indeed stretched to accommodate entities that are not sovereign states, although the decision to make such accommodations is still vested in those sovereign states. Others also seek to simulate established conventions of diplomacy but their presence in the antechamber has much less resonance, for they can call upon no sanction, save that of a possible patron state or a handful of supporters among the ranks of the sovereign membership of international society. The fact that they are allowed to set up shop at all in accepting capitals is, of course, an acknowledgement of their presence; but, typically, this is countered by strict protocols of neglect and non-engagement.

For those jurisdictions without such sanction, there are still opportunities to participate in this antechamber, but the qualitative substance of that participation is very different: they remain quarantined in spite of their frantic activity. They are pariahs, near pariahs or simply ignored in even those basic channels of acknowledgement readily granted to sanctioned sub-national participants in the antechamber.

Para-diplomacy is the outreach of non-sovereign jurisdictions to actors beyond their own borders and the frontiers of their metropolitan relationships or claimant states. It may involve direct contact with sovereign states with which the metropolitan centre already enjoys diplomatic relations. It may include formal channels with other sub-national jurisdictions participating in areas of functional cooperation, perceived mutual economic advantage and cultural exchange. It may include associate membership or even full membership in intergovernmental organizations, particularly at the regional level (Corbin, 2001, pp. 136-159). Para-diplomatic missions may be simple and understated, a government mission of non-diplomatic status with an ad boc and general mandate of representation and information gathering. This may be an office to promote tourism or trade initiatives. Similarly, non-sovereign jurisdictions may be the recipients of such para-diplomatic missions and even of consular offices. Para-diplomatic missions may even stretch the cosmetic features of the mission to simulate full diplomatic status, even though the actual accreditation falls well short of legal recognition, typical of the activity which Martin Lubin terms 'proto-diplomacy'.

Because most sub-national para-diplomatic missions are in functional areas of representation, they are frequently viewed as benign by the metropolitan centre. Nonetheless, benign or not, they do allow a non-sovereign jurisdiction to reach out beyond and around the metropolitan centre to engage in independent exchanges with the outside world. This can be particularly valuable if the sub-national jurisdiction can participate in intergovernmental organizations with its own delegation and under its own auspices and thus with direct access to sovereign governments around the world. Québec has long aspired to a separate delegation at UNESCO and recently the newly elected Canadian prime minister, Stephen Harper, indicated that his Conservative government is ready to concede this issue (Séguin, 2006, A5). UNESCO and other specialized agencies allow for associate membership, which grants participation in the agencies' deliberations but without a vote. If this is the formula adopted for Québec, then the province will join Aruba, the Netherlands Antilles, the British Virgin Islands, Tokelau, Cayman Islands and Macao as sub-national associate 
members in UNESCO (Corbin, 2001, p. 143). Yet the Cook Islands and Niue enjoy full membership of UNESCO, raising intriguing questions concerning their international status.

The legal rights of sovereign states have long been prized by entities seeking international recognition. It is one reason why so many advocates of national selfdetermination in the period of postwar decolonization could settle for nothing less than sovereignty as the full and final culmination of the self-determination process. Sovereignty provided a once dependent territory with a 'green card' with which to engage the international system fully and with legal equality on its own terms. It would be folly to underestimate the huge symbolic appeal of separate international legal personality for many dependent territories, however rational and persuasive the functional arguments for alternative forms of constitutional status might be. In no situation is the right to full international legal personality more cherished or coveted than in de facto states, where actual independence on the ground has meant little in their efforts to win international acceptance. The 30-year quarantine of the Turkish Republic of Northern Cyprus (TRNC) would argue powerfully for the substantive capacities of recognized international legal personality (Bartmann, 1999, pp. $260-$ 286). In the case of the TRNC, as in other unrecognized states, governments do engage in a necessarily low level of para-diplomacy; but this is still not sufficient to circumvent the punitive realities of their own pariah status.

\section{AMBIGUITIES OF STATUS: THE BRITISH DOMINIONS AND THE EUROPEAN MICRO-STATES}

If we consider the historical development of the twentieth-century state system, the apparent ambiguities of status and privilege concerning international representation are not unique to contemporary developments. With the establishment of the League of Nations in 1919, a shift to an inclusive and egalitarian ethos in international relations was clear and with it the problems of status and rights attending issues of membership. The international legal status of some founding members of the League was not unlike that of many of today's small island sub-national jurisdictions. League membership was seen to be an acknowledgement of international legal personality, 'fledgling' though it might be (Granatstein and Hillmer, 1991, p. 74), given the emphasis placed on the capacity of member states to fulfil their obligations under the Covenant, particularly Article 16, with its expectations of collective responsibility.

The historic narrative in this context is one of ambiguity and mixed signals. While accepting India, still a British colony, or Britain's dominions, as members of the League, the Admissions Committee refused the application of Liechtenstein, a longstanding European principality whose sovereignty and statehood the Committee acknowledged and whose application was enthusiastically sponsored by Switzerland (Gunter, 1974, pp. 496-501). Liechtenstein's rejection reflected assumptions about the nature of sovereignty and the attributes of statehood that were conventional at the time: in 1919 Liechtenstein initiated agreements with Switzerland which included Switzerland's representation of Liechtenstein's interests abroad when called upon to so act by the government in Vaduz. Most of these agreements did not take effect until after Liechtenstein's application had been rejected (Raton, 1970, pp. 76-77). Nevertheless, the Committee reasoned that because Liechtenstein had "chosen to 
depute to others some of the attributes of its sovereignty ... we are of the opinion that the Principality of Liechtenstein could not discharge all the international obligations which would be imposed on it by the Covenant" (League of Nations, 1920, p. 667). Yet other members, notably self-governing Dominions and colonies, did not possess the 'attributes of sovereignty' which Liechtenstein was alleged to have 'surrendered'. As Michael Gunter concluded: "the real reason for the rejection of Liechtenstein was her smallness, not her deputation of some sovereign attributes" (Gunter, 1974, p. 499). Moreover, as he further noted, Liechtenstein's rejection was "by inference" a rejection of "other ministates which might apply in the future" (Gunter, 1974, p. 499). Indeed, Luxembourg proved to be the single, notable exception (Hudson, 1935).

Iceland's constitutional status in the Danish Realm was not unlike that of the Dominions in the British Empire. Iceland did approach the League in 1918 through the French Foreign Ministry and it did so again in 1930, the 1000th anniversary of the Althing. But Icelanders showed little enthusiasm for League membership because, as Jónas Jónsson, Minister of Justice at the time, put it, "of smallness, poverty and a kind of shyness" (Gröndal, 1974, p. 25). Iceland's representations and interests in the world continued to be conducted by the Danes, although Iceland maintained an embassy in Copenhagen and posted Icelandic trade attachés to some embassies and consulates. With Germany's invasion and occupation of Denmark in 1940, Iceland established missions of its own in Washington, London and Moscow (Gröndal, 1974, p. 25). With independence in 1944 Iceland developed a full diplomatic service. For the other European micro-states, their international relations were confined to the margins of international diplomatic practice during this long interregnum. While they were sovereign states and ceremonially treated as such, in substance their external relations were para-diplomatic in nature and highly qualified; much the same as the external relations of non-sovereign jurisdictions today.

\section{PARADIPLOMACY AS A STATE-BUILDING INSTRUMENT FOR DE FACTO STATES}

The end of the decolonization process may be symbolically recognized in the final transfer of sovereignty to East Timor. But it was also marked by the international admission of 'leftovers' of the Westphalian system where events finally caught up with their long neglect. After St Kitts and Nevis, São Tomé and Príncipe, and the Seychelles, what residual arguments could be mounted against Liechtenstein, the most industrialized country per capita in the world, or San Marino, the oldest continuing sovereign state in Europe? In short, the eventual course of self-determination weakened whatever inhibitions constrained these states and the residual resistance within the international system itself, thus emboldening them to leave the antechamber and gatecrash the grand hall.

These 'state-building' functions of para-diplomacy are still powerful motives for some non-sovereign jurisdictions and players beyond the pale of normal international relations. For unrecognized, de facto states the search for legal recognition and the formal acknowledgement of their legal existence as self-governing nations are the core issues of their agenda. The TRNC is recognized by Turkey, of course, but it is a pariah state everywhere else, even in Europe, where its territory lies within the European 
Union. The Cyprus issue is truly a bizarre combination of fiction and pretension. The territory of the TRNC is legally part of the space of the European Union but subject to an EU blockade. The TRNC is even shunned officially in the Islamic world, where there are prominent non-official constituencies of co-religionists and even muted empathy in official corridors. The TRNC has established, in addition to its embassy and consulates in Turkey, a network of representatives or missions in key capitals (see Table 5.1), but the nomenclature remains as ambiguous as the status of its personnel. Even in this understated presentation, these missions remain off the radar screen of official exchange.

In the TRNC case host countries insist these missions be registered as The Office of the Representative of the Turkish Cypriot Community and, of course, their personnel cannot claim diplomatic visas, an issue which presents recurring problems for the officers at these stations. For the missions in the Islamic capitals the rules of the European blockade are not in effect and consequently these missions are designated with a more official status as Trade and Tourism offices. But in Geneva, the mission exists physically and functionally as part of Turkey's permanent mission.

\section{THE ANOMALY OF TAIWAN}

There are certain entities which seek similar acknowledgement as the de facto states discussed above. These are governments-in-exile whose territory lies beyond their reach and, indeed, whose separation from that territory may span many generations as their lonely diplomats seek to keep the flicker of their national candle alive in distant capitals. At one time, when international divisions were more profound, these governments were common, particularly for the German-occupied territories during World War II. In the postwar years Western powers allowed the Baltic states of Estonia, Latvia and Lithuania to maintain their legations and did not recognize their legal incorporation into the Soviet Union, even as they acknowledged that these three republics were functioning as units subject to Soviet law and practice. In the contemporary international system the Chinese occupation of Tibet since 1949 continues to provoke anti-Chinese and pro-Tibetan demonstrations and activities around the world.

Yet, difficult as the question of Tibet is for China, Taiwan is the most pressing issue. The Republic of China on Taiwan may be superficially regarded as a

Table 5.1 Para-diplomatic missions of the Turkish Republic of Northern Cyprus

TRNC, Representatives Offices

London: Office of the Representative of the Turkish Cypriot Community Baku: Trade and Tourism Office of the Turkish Cypriot Community

Brussels: Office of the Representative of the Turkish Cypriot Community Washington: Office of the Representative of the Turkish Cypriot Community

New York: Office of the Representative of the Turkish Cypriot Community, UN Plaza

Islamabad: Trade and Tourism Office of the Turkish Cypriot Community

Abu Dhabi: Trade and Tourism Office of the Turkish Cypriot Community

Geneva: Office of the Representative of the Turkish Cypriot Community, Permanent Mission of Turkey

Source: www.trncgov.com/representativesoffices.htm. 
government-in-exile. The Taipei government continues to maintain, after nearly 60 years, that it is the legitimate government of the whole of China. Of course, the island government maintains authority only over Taiwan itself and a handful of offshore islands. Nevertheless, 23 countries in the world recognize Taiwan (as the Republic of China) and allow it to have an embassy (along with Panama, which maintains a Taiwan Consulate-General). Fifteen countries (Belize, Burkina Faso, Dominion Republic, St Kitts-Nevis, Swaziland, El Salvador, The Gambia, Honduras, Marshall Islands, Nicaragua, Palau, Panama, Paraguay, São Tomé and Príncipe, Solomon Islands) have a resident diplomatic embassy in Taiwan. For 66 other countries, however, many with extensive and hugely important economic links to Taiwan, relations are of a purely para-diplomatic nature and - given China's own preoccupation on this issue - with a highly sensitive nomenclature to describe 'nonofficial' missions, although they may very well operate as de facto embassies. (Indeed, the most common nomenclature for the Taiwan office in their country is 'Taipei Economic and Cultural Office'.) For 57 of these countries there are para-diplomatic resident missions in Taipei, with such names as the Argentina Trade and Cultural Office, the Malaysia Friendship and Trading Centre, and American Institute in Taiwan. Similar cosmetic fudging has allowed for some Taiwanese participation in international bodies such as the Olympics and for direct personal representations between Taiwanese government leaders and their counterparts in other states. In short, Taiwan is at once a normal state, a government-in-exile and a de facto state engaging in both official and internationally recognized channels of diplomacy in some cases and cloaked para-diplomatic exchanges in others. Taiwan is an international anomaly both in and out of the antechamber (see www.mofa.gov.tw).

What is perhaps most striking here is that Taiwan, a major regional economic and military power, and one of the most stable democracies in Asia, is still very dependent on para-diplomacy in the antechamber of international relations. The official and recognized delegations which Taiwan receives as the Republic of China are confined to very small states, themselves on the margins of the international system. In contrast, Taiwan's para-diplomatic reach is dramatic in the status of its state partners and in the sheer numbers of its own para-diplomatic operations abroad. Similarly impressive is the number of major states (57) which maintain para-diplomatic missions on the island. In short, in spite of its economic clout and its strategic stature, Taiwan continues to engage the international system on two different levels; and it is the more informal, unofficial, para-diplomatic level which clearly provides for this controversial island's most critical relationships. Of course, this speaks to the depth of the taboo of Taiwanese separation and the paramount urgency of the territorial integrity principle for mainland China. Nevertheless, these circumstances also reflect the very elasticity of the para-diplomatic mission. The nomenclature chosen can convey simply a non-governmental relationship, so as to emphasize the distance between the emissary state and Taiwan. Note that some of the designations of foreign missions in Taipei are those of non-governmental bodies, such as the Swedish Trade Council or the Spanish Chamber of Commerce. Others, perhaps less sensitive to mainland sensibilities, even go so far as to include 'The Republic of China' in the registration of their offices in Taipei. Taiwan's own offices abroad indicate a fairly common standard, with an emphasis on trade, investment and cultural exchanges. In any case, both the para-diplomatic Taiwan missions abroad and the foreign paradiplomatic missions in Taipei carry on many substantive diplomatic duties. Taiwan's 
unique position in the international system enables it to follow established diplomatic protocols in some situations but to resort to para-diplomacy in most of its critical relationships with other states. Taiwan's major activity in an international organization is its membership in the World Trade Organization, where it maintains a regular permanent mission, although it comes under the awkward title of the Special Customs Territories of Taiwan, Penghu, Kinmen and Matsu.

\section{THE PARADIPLOMATIC ACTIVITIES OF SUB-NATIONAL ISLAND JURISDICTIONS}

The non-sovereign small island jurisdictions across the globe represent as broad a tapestry as any we have examined thus far. Some of them are still in essentially metropolitan relationships with European states: the non-sovereign islands in the Caribbean, for example, are British, French or Dutch territories, or very closely linked to the USA. Apart from the French-administered island territories in the South Pacific, and the lonely British island of Pitcairn, the small islands of this region are in varying associated relationships with Australia, New Zealand and the USA. There are many small islands which are essentially municipal, county or occasionally provincial jurisdictions of mainland states. And there are those European islands, the Danish and Finnish home rule territories and the ancient Crown dependencies of the Channel Islands and the Isle of Man, with a very distinctive constitutional status.

Para-diplomatic practices are being established and developed in several of these islands and, like the regions of the European Union, these activities vary in terms of the primacy given to political and identity issues and a more modest economic and functional agenda. It may seem surprising that the Crown dependencies, among the most historic of European jurisdictions and independent in so many respects, have not been drawn to separate representation beyond their shores. The British Home Office conducts whatever relations are necessary with Brussels or any other capital as issues arise. There has been no groundswell in these islands for a separate para-diplomatic network apart from these trusted good offices.

In some islands, however, there is a question of national island identity, which has encouraged an international projection of the island in the establishment of paradiplomatic offices. The Faeroe Islands are an example of the blend of identity and functional interests that make para-diplomatic representation attractive for many sub-national jurisdictions. The national question or the home rule question has dominated Faeroese politics throughout the postwar period. Following Maurice Duverger's model of "overlapping or equally competing cleavages" (Duverger, 1959, pp. 231-33), Faeroese political scientist Jogvan Mørkøre has argued that this question has been as divisive in Faeroese politics as the conventional social-economic state-market divisions on a familiar left-right continuum, thus producing a multiparty system with party formations based on ideological mixes across these two definitive issue-areas (Mørkøre, 1997, pp. 162-191).

Following the German invasion of Denmark in April 1940, the British occupied the islands and urged the islanders to fly their own flag at sea rather than the Danish red and white cross (Schei and Moberg, 1991, pp. 40-41). The years of British occupation were for "all intents and purposes, a period of Home Rule" (Schei and Moberg, 1991, pp. 40-41), which paved the way for a Danish-crafted referendum in 
September 1946, offering a choice between independence and some form of selfgovernment within the Danish Realm. Although the vote was exceedingly narrow (5650 for independence against 5500 for union), the Danish government initially accepted the results, as did the Faeroese Løgting. But the Danes soon rescinded their position, the Logting was dissolved and new elections resulted in a government in favour of autonomy within the Union. The result was the Home Rule Act of 1948, in which the Faeroes were made "a self-governing community within the Danish Realm" enjoying a wide latitude of autonomy in domestic affairs, although foreign affairs and defence remained the prerogative of the Danish government in Copenhagen. The debate over independence did not abate, however, and in 1999 the Faeroese government, now led by a coalition committed to independence, laid out a detailed schema for an independent Faeroese state. One of the key chapters in this 'White Book' looked to the future international relations and security policy of an independent Faeroese state (see Table 5.2).

The Faeroes currently maintain three representative offices: London and Brussels with diplomatic status and Copenhagen without diplomatic status. The offices in London and Brussels "are located within the Danish embassies and the Faeroese diplomats are formally accredited to the respective host nations as Danish diplomats working with Faeroese affairs" (Isfeld, 2006). The Faeroese missions could be housed in another location, although they would still be regarded as part of the Danish Embassy. This arrangement is not unlike the position of the Canadian minister in the British Embassy in Washington in the years following World War I. And it is an arrangement in keeping with the Danish practice of providing means and channels for Faeroese representatives to speak directly to third parties on issues of importance to the Faeroes (Olafsson, 2000, pp. 127-129). Moreover, this para-diplomatic activity reflects further changes in the relationship between Torshavn and Copenhagen. On 29 July 2005, a new law involving the Islands' external relations came into effect. It allows

the Faeroese government to enter into negotiations and conclude treaties with other states and international organizations without previous consent from Denmark regarding all areas that are under the Faeroese authorities... The Faeroes can accordingly negotiate and conclude on its own [emphasis added] a bilateral treaty with another state regarding trade, culture, fisheries or any other

Table 5.2 Expected diplomatic establishment of an independent Faeroes as set out in White Book of 1999

Reykjavik: Embassy

Oslo: Embassy, accredited to Moscow

Copenhagen: Embassy, accredited to Stockholm, consular office in Helsingfors

London: Embassy, accredited to Dublin

Washington: Embassy, accredited to Canada, Mexico and Central and South American states Brussels: Embassy, accredited to all European states, except Norway, Russia, UK and Ireland: accredited to the European Union, OECD, WTO, NATO, OSCE

New York: Permanent Mission to the UN, accredited to Asian and African states

Source: Government of Faroes (1999, pp. 75-77). 
business where the legislation and execution in the Faeroes lies with the Faeroese authorities.

(Isfeld, personal communication, 20 January 2006)

This gives considerable substance to a Faeroese para-diplomatic network and is a clear demonstration of shared responsibilities between sovereign and sub-national governments, even in the sensitive areas of foreign policy typically seen as exclusively the prerogatives of the sovereign state (Olafsson, 2000, pp. 127-129).

There have been even more dramatic developments of late. In September 2007, the Faeroes opened a mission in Reykjavik as indicated in their 1999 White Book wish list. In December 2007, the Faeroes became an associate member of the Food and Agricultural Organisation (FAO) (www.tirnganes.fo). Following the January 2008 elections, a new three party coalition government was formed with the Social Democrats, the Independence Party and the Centre Party. Høgni Hoydal, the leader of the Independence Party, became Minister of Foreign Affairs (www.tinganes.fo). There are now plans to open three more Faeroese missions: in Geneva, Moscow and New York, bringing the total number of Faeroese offices of representation to seven (Jóannes Vitalis Hansen, Faeroese Civil Service, personal communication, June 2008).

There is a similar permissive latitude in the case of the other Danish home rule island territory, Greenland, although there has not been a comparable 50-year debate on the issue of home rule or independence. Greenland representatives have a similar power to negotiate directly on issues within the purview of the Home Rule Government (Larsen, 1992, pp. 219-220; Motzfeldt, 1997, pp. 193-194). Greenland maintains Representative Offices in Copenhagen and Brussels, the latter a direct monitoring base of EU developments that could directly affect the island (see www.Nanoq.gl/english.aspx). Both the Faeroes and Greenland host consulates from major European states. There are nine consulates in Torshavn: Finland, France, Germany, Iceland, Italy, Netherlands, Norway, Sweden and the UK. There are also nine consulates in Nuuk: Belgium, Canada, Finland, France, Germany, Iceland, Netherlands, Norway and Sweden. Moreover, both Greenland and the Faeroes sit as separate members of the Nordic Council of Ministers. (The three Baltic states have observer rights.) This participation in an important intergovernmental organization allows for relations with other member states and assures both territories of a genuine role in regional issues of importance to them.

The case of the Alland Islands is particularly interesting. Its status is unique since it is rooted in international law as the consequence of a decision of the League of Nations. Given the many particular jurisdictional guarantees which the Ålands can claim under the Autonomy Act with Finland (Myntti, 2002, pp. 107-124), the islanders had the right to determine whether or not they would join the European Union. In theory, Finland could have acceded to EU membership while the Ålands stayed out. Their autonomous status is also reflected in their separate membership in the Nordic Council, a privilege which they share with the Danish home rule territories. They are then in a position to reap the benefits of direct relations with their regional partners (Anckar and Bartmann, 2000).

However, their situation with the European Union is not as satisfying as initially expected. The Ålanders were able to extract some critical derogations from Brussels during the accession negotiations, particularly on the economically critical issue of continued duty-free shopping on Åland ferries (Scarpulla, 2002, pp. 138-141; 
Jansson, 2002, pp. 201-212). Duty-free arrangements were abolished elsewhere in the European Union and this concession was certainly significant and contributed immensely to the $74 \%$ vote in favour of membership in the November 1994 referendum (Åland Legislative Assembly). However, since this initial success, islanders have become more disenchanted with the Union over a number of issues that are deemed important to their way of life and even their economic well-being. The first EU negative decision was the banning of traditional nets by island fishers, a decision that applied across the EU. This was followed by the abolition of spring duck hunting and most recently the banning of snus, a Swedish chewing tobacco, which is allowed only in Sweden, a special derogation to Stockholm and (until now) the Ålands. Snus chewing is a habit enjoyed by many Islanders, even though Finland accepted the ban on the mainland. Since Finland cannot change laws covering health in the Ålands, the parliament in Helsinki has no power to change the law on snus. The real problem here is one central to our discussion: a lack of direct representation. Although there is an Åland representative presence in the Finnish delegation in Brussels, the Åland Islands cannot represent themselves directly in Brussels on issues which are exclusive to them or primarily affect them. In an angry reaction over the snus controversy, Britt Lundberg, the Ålands head of EU affairs, has threatened to use the power to veto any Finnish international treaty. The threat implies that Åland will thwart Helsinki's commitment to revive the moribund European Constitution when Finland assumes the rotating presidency of the European Council later in 2006 (Rennie, 2006). While the Åland Islands maintains representatives in Stockholm, Helsinki and Brussels, it is a rather 'toothless' arrangement if Åland cannot make its own case directly. The European Court in Luxembourg will hear only from member states, clearly a provision that denies the regions a capacity which is the very logic of para-diplomatic representation.

Neither the Faeroes nor Greenland is subject to such EU edicts. The Faeroes did not join at the time of Danish accession and Greenland seceded from the EU in 1985, the only territory yet to do so, after achieving home rule government in 1979. The Danish permissive policy, to include Faeroese and Greenlandic representatives in negotiating arrangements which directly affect their interests (e.g. on the Nordic Council), is an optimal and positive template for small sub-national jurisdictions. It speaks to the very purpose expected of para-diplomatic activity among sub-national governments, an opportunity to reach out and address their particular interests while remaining inside a metropolitan relationship which offers many benefits to the citizenry of these territories.

The efficacy of regional institutions as channels for the international outreach and representation of sub-national or non-sovereign territories is particularly well established in the Commonwealth Caribbean. Caricom, the Caribbean Community, has 15 member states, which include the very small island of Montserrat. If, at one time, Montserrat contemplated independence, any prospects were dashed by the 1995 eruption of the Soufrière volcano, which destroyed the capital, Plymouth, and forced the emigration of 8000 islanders, two-thirds of the population. Some have returned, but the island's habitable space is now confined to a small section of the northwest. Soufrière erupts regularly and the island has been continually hit by hurricanes. In short, the status of Montserrat as a British overseas territory is unlikely to change. The same may be said of the other very small British islands in the Caribbean: Anguilla, the British Virgin Islands, the Cayman Islands and the Turks and Caicos 
Islands. Along with Bermuda, where independence is being debated, these four small island territories are associate members of Caricom. Anguilla, Montserrat and the British Virgin Islands are also among the nine full members of the Organization of Eastern Caribbean States (OECS). Thanks to these two major regional bodies the smallest non-sovereign islands have an extensive 'diplomatic reach' which largely mitigates the need for and the appeal of sovereignty. Moreover, the OECS has its own diplomatic missions in Ottawa and Brussels, which allows Montserrat and the other very small island members a direct diplomatic channel to the outside world. Caricom maintains a permanent observer mission to the UN in New York, which is another channel of outreach for its non-sovereign members and associate members. These are generous and practical measures in keeping with a spirit of flexibility concerning status and privileges for non-state jurisdictions.

Bermuda stands apart from the other British overseas territories in the region since independence has been a matter of domestic debate for some years. In the referendum of 16 August 1995 the independence option was defeated, but largely because the parties could not agree on the appropriate vehicle for achieving independence. The Progressive Labour Party, which has long advocated independence, has subsequently won two national elections and in 2004 Premier Alexander Scott established the Bermuda Independence Commission (BIC) to revisit the issue. The Commission was chaired by Bishop Vernon G. Lambe and its report was published in August 2005. The Commission's work involved wide-ranging consultation with the British government, the US Department of State, Canada, the European Union, and various countries of the region (BIC, 2005).

At present the UK is responsible for Bermuda's external affairs both as the island's interlocutor with other states and its representative in major intergovernmental associations apart from Caricom. In the current arrangements, however, Bermuda does have input into issue-areas which directly affect the island. The Bermuda Independence Commission noted these provisions in its 2005 report:

Britain, in negotiating a treaty on Bermuda's behalf, receives input from the Bermuda Government regarding matters affecting Bermuda and, in turn, the British Government keeps Bermuda appraised of the progress of the negotiations. At times Bermuda representatives are present as observers. The British Government has delegated some authority for certain treaty negotiations to Bermuda through the 1968 Entrustment. With greater frequency, Ministers of the Bermuda Government are, with prior approval, thus permitted to negotiate certain agreements, provided that they keep the British Government informed. One example is the Tax Convention that Bermuda was allowed to negotiate directly with the US.

(BIC, 2005, p. 17)

These arrangements approximate those in place for the Danish home rule territories. On the other hand, Bermuda has not sought a high-profile network of paradiplomatic representation. Bermuda maintains tourist offices in Atlanta, Beverly Hills, Boston, London, New York and Toronto. Unlike other British small island overseas territories (Anguilla, British Virgin Islands, the Cayman Islands, Falklands, Montserrat, the Turks and Caicos, and St Helena), Bermuda does not have a Representative Office in London (see www.embassies.com). However, there are two 
consulates (Portugal and the USA) and 16 Honorary Consuls resident in Hamilton: Austria, Belgium, Canada, Denmark, Finland, France, Germany, Ireland, Italy, Jamaica, Luxembourg, Netherlands, Norway, Spain, Sweden and Switzerland (Bermuda Embassy and Consulate Listing, 2008).

Independence for Bermuda would mean virtually starting from scratch. With this in mind, the Bermuda Independence Commission envisaged two options for the establishment of a Foreign Ministry and diplomatic staff. It is interesting to compare these projections with those of the Faeroese White Book of 1999 discussed above. Option One (total projected annual costs: \$1336000) would upgrade the Tourism Office in New York to a diplomatic mission, along with the establishment of an embassy in Washington and high commissions in Ottawa and London. Bermuda's relations with the European Union would be handled from either Bermuda or London. Bermuda would join the UN and its lead agencies and the Commonwealth (BIC, 2005, pp. 43-44). Option Two (total projected annual costs: $\$ 3051000$ ) also expects that Bermuda would join the UN and its agencies, and the Commonwealth, with possible full membership of Caricom if this did not involve the Caribbean Single Market and Economy or the Caribbean Court of Justice (BIC, 2005, pp. 44-45). Independence could mean membership in other agreements such as the North American Free Trade Agreement, the Organization of American States, the World Trade Organization, the Free Trade Area of the Americas, the Inter-American Development Bank, and the European Union's Africa Caribbean Pacific (ACP) organization. Overseas missions would be established in Washington, Ottawa, New York, London and Brussels. The report suggests that, in the many countries where Bermuda would not have a mission, it would continue to rely on the UK to represent its citizens and interests and the reimbursement costs of these services are factored into the report's projected costs of independence. The report is confident that, in the end, the costs of independence "would not be outside the affordability of Bermuda" (BIC, 2005, p. 59).

Of course, costs and benefits cross a broad range of issues. In response to the report, the Royal Gazette noted that the issue of a British passport was 'glossed over', a privilege which presently gives Bermudians the right to live and work anywhere in the European Union (Royal Gazette, 2005). "And", the Gazette warns, "once it is lost, it would almost certainly be gone forever". But the Gazette also notes that: "For some black Bermudians, in particular, Independence represents a final act of freedom" (Royal Gazette, 2005). This echoes the clear symbolic priority in the report for the Progressive Labour government:

Some Black Bermudians associate Bermuda's current colonial status as being only slightly removed from its history of slavery and segregation. An advantage for them is the logical and necessary step towards full emancipation. This may be a difficult concept for some in the White community to grasp; but, until they do, it is nigh impossible to have a meaningful debate on the subject... here is a significant sector of the Bermudian population who feel that full emancipation, full adulthood and full equality may only be achieved when the last vestiges of colonialism have been removed.

(BIC, 2005, pp. 61-62)

Clearly, this debate would not be conducted in most of the small non-sovereign islands subject to metropolitan relationships. But in Bermuda it lies at the core of the 
question. A detached assessment of Bermuda's status would suggest that the island's current relationship with the UK is largely beneficial, even in terms of external links and overseas representation. Yet it is precisely in this area that the report concludes there would be clear gains with independence: "A distinct advantage to an independent Bermuda could be the value of international relationships and organizations and the expertise available to emerging nations" (BIC, 2005, p. 62). Clearly the case for para-diplomatic outreach within a continuing metropolitan relationship has not been conclusive in the Bermuda debate.

In the South Pacific there is a pattern of permissive arrangements both in terms of regional intergovernmental bodies and in the particular latitude granted by New Zealand with the status of free association. The Pacific Islands Forum represents the heads of government of all its 16 members. The Cook Islands and Niue, both states in free association with New Zealand, are full members (see www.forumsec.org.fj). Most remarkable for this discussion is the international legal personality of these territories. New Zealand officially describes the Cook Islands as "a self-governing state in free association with New Zealand" (Government of New Zealand, n.d., p. 7). "New Zealand cannot make laws for the Cook Islands...the Cook Islands Government has full executive powers... The Cook Islands remains a part of the Realm of New Zealand (albeit a separate part) ... Cook Islanders retain New Zealand citizenship (and do not have additional Cook Islands citizenship" (Government of New Zealand, n.d., p. 7).

The separate international legal personality of the Cook Islands, given their New Zealand citizenship, truly illustrates the elasticity and innovation possible within the context of 'dependent relationships' (see Table 5.3).

Moreover, the Cook Islands has established separate diplomatic relations with over 20 states at embassy or high commission level. The Cook Islands High Commission in Wellington is also accredited as the Cook Islands High Commission to Australia, Papua New Guinea and Fiji. The Cook Islands Embassy in Brussels is also accredited to the European Union. There are in fact no fewer than 23 states (including Australia, New Zealand, the USA and the European Union) with full diplomatic relations accredited to the Cook Islands at the embassy or high commission level. There is also a supplementary consular network with honorary consuls for the Cook Islands in Honolulu, Los Angeles, Oslo, Sydney and a consulate-general in Auckland. There are honorary consuls in Avarua Town for the UK, France and Germany and a warden for the USA. The Cook Islands has

Table 5.3 Membership of the Cook Islands in international organizations

Asian Development Bank

Food and Agriculture Organization

World Health Organization

United Nations Educational, Scientific and Cultural Organization

Commonwealth (Associate member)

UN Economic Commission for Asia and the Pacific (Associate member)

Pacific Islands Forum

Secretariat of the Pacific Community

Source: Government of the Cook Islands (2005). 
independently concluded treaties with a number of states, including China, the USA, the Republic of Korea and France (Government of the Cook Islands, 2005). This very small state is also an independent signatory to several multilateral conventions, including the Cotonou Agreement between the ACP states and the European Union.

A similar status is enjoyed by Niue, also a self-governing state in free association with New Zealand, but on a more modest scale. New Zealand has a high commission resident in Alof, Niue, and, astonishingly, Niue maintains a high commission in Wellington and shares an ambassador and embassy with the Cook Islands in Brussels, although the two states are accredited separately (see www.embassypages.com).

Even in Tokelau New Zealand will only act on behalf of this tiny territory if instructed to do so by the government of Tokelau. This was precisely the arrangement for Swiss representation of Liechtenstein until the late postwar years, an arrangement which many jurists insisted at the time was one that unequivocally established the sovereignty of the principality (Farran, 1960).

The Cook Islands has not presented itself to the international community as a sovereign state, although it behaves in exactly that fashion in its international relations. Cook Islanders are New Zealand citizens and that citizenship is clearly of value in itself, given the large Cook Islands population in New Zealand. The islanders are able to enjoy all the prerogatives of sovereignty with the most permissive and generous arrangements for international relations available to any dependent territory in the world. Indeed, to return to our opening historical discussion, the Cook Islands today enjoys an official diplomatic reach beyond the smallest European states before 1990, even though the European micro-states were classified, at least formally, as sovereign entities at the time.

In short, these are arrangements far beyond what is understood to be the various practices of para-diplomacy. When a territory has the separate and independent legal capacity to enter into full diplomatic relations with other states, to send and receive missions at the embassy level, to negotiate bilateral treaties, to be a signatory to multilateral conventions, to participate independently in intergovernmental organizations, especially when those organizations' membership is confined to sovereign states, then what is possibly left to meet the full international legal personality of sovereignty?

Only UN membership remains absent for the Cook Islands, but this was never a litmus test unto itself. Until very recently some states did not apply for UN membership, even though their sovereignty was not in question: (Western) Samoa achieved independence in 1962 but did not join the UN until 1976.

\section{CONCLUSIONS}

The twenty-first-century international system is more universal and inclusive in that full international legal personality is shared by jurisdictions which would have been considered improbable and absurd as sovereign states even in 1960 at the beginning of the mass suffrage of colonial territories. Indeed, the apparent ambiguities of status and international prerogatives beyond decolonization have reinforced an ongoing trend to universalism and inclusiveness, a trend which is dramatically 
reflected in the expanding opportunities and practices in the antechamber of paradiplomacy.

Across this comparative and historical view of para-diplomatic practices there is a consistent pattern of muddied credentials for access to and status within the central international channels of diplomacy. Moreover, there are very different kinds of entities to be found in this antechamber and it is important to retain a clear sense of these distinctions when assessing the phenomenon of para-diplomacy in general. Some of these distinctions have been noted in the current literature on paradiplomatic practices among sub-national units in federations and regions in the European Union. There are jurisdictions which entertain 'national' or 'identity' agendas with pressing political objectives: Québec, Flanders, Catalonia, and to some extent even certain small island sub-national entities such as the Faeroes. Most others engage in para-diplomatic practices for relatively modest functional objectives, and these efforts are almost entirely focused on information: "they gather information concerning [EU] legislation; they exchange information in subnational networks; they mediate information to their respective home territories, and they provide information to [EU] decision makers" (Marks et al., 2002, p. 2).

Are some of the entities more likely to develop or win para-diplomatic practices than others? Clearly those jurisdictions with a distinct identity agenda can be expected to pursue a para-diplomatic outreach aggressively. And small islands, because of their physical separateness and insularity, are obvious candidates for the same reasons that they have gained self-government and even constitutional separateness. However, all sanctioned para-diplomatic practices function within the context of a national or metropolitan relationship and with the consent of the central government. To be sure, agitation and political pressure for greater status recognition and external access from the jurisdiction itself may well result in the central government moving cautiously beyond its own initial comfort levels. But it is a sphere which is only accessible if the metropolitan or central government agrees. It is not some new and swampy terrain of international relations which sub-national governments can enter by stealth. It is not a case of a state being ambushed by its dependent units, suddenly, awkwardly and embarrassingly discovered in the antechamber by sheer chutzpah. No, there are guards at the door and credentials are checked; only those with a metropolitan stamp of approval are admitted. The Faeroes mission in London, the Montserrat delegation at Caricom and the Cook Islands Embassy in Brussels function within the legitimacy of external representation as acknowledged by their metropolitan centres and therefore by the international system itself.

Para-diplomacy is not a new and innovative sphere of international relations, much less one that undermines the finality of sovereign states' judgements on international status and access. Para-diplomacy is not a breach of conventional distinctions in diplomatic practice as much as a redefinition of the frontiers of domestic authority within sovereign states, conceding practices which central governments in some cases have come to accept and even promote for their dependent territories. Indeed, in those cases where para-diplomacy seems to be most advanced and conventional distinctions of status most blurred, the new parameters of international engagement and outreach are determined in the end where they have always been determined: in the capitals of the sovereign members of the international system. 


\section{References}

Anckar, D. (2002) Åland as a micro-state: the independence scenario, in H. Jansson and J. Salminen (Eds), The Second Aland Islands Question: Autonomy or Independence?, pp. 213-242 (Mariehamn: Julius Sundbloms Minnesstifelse).

Anckar, D. and Bartmann, B. (2000) Ett ramverk för ett självständigt Aland (Mariehamn: Sällskapet Ålands framtid).

Bahcheli, T., Bartmann, B. and Srebrnik, H. F. (Eds) (2004) De Facto States: The Quest for Sovereignty (London: Routledge).

Bartmann, B. (1998) The future political foundation for territorial policy in a global context, in B. Lindström (Ed.), Den Regionala Utmaningen: Territoriell politik I ett europeiskt Norden, pp. 239-250 (Stockholm: NordREFO).

Bartmann, B. (1999) The quest for legitimacy: international status of the TRNC, in C. H. Dodd (Ed.), Cyprus: The Need for New Perspectives, pp. 260-286 (Huntingdon: The Eothen Press).

Bartmann, B. (2000) Patterns of localism in a changing global system, in G. Baldacchino and D. Milne (Eds), Lessons from the Political Economy of Small Islands: The Resourcefulness of Jurisdiction, pp. 38-55 (London: Macmillan).

BIC (2005) Report of the Bermuda Independence Commission, Government of Bermuda, August, at www.bermudaindependencecommission.bm

Bermuda Embassy and Consulate Listing (2008), Bermuda 4U: A Comprehensive Guide to the Rock, www.bermuda4u.com/Essential/bermuda-embassy.html.

Chapman, P. (2006) Tiny Tokelau decides that self-rule is too expensive, Daily Telegraph, 18 March.

Corbin, C. (2001) Direct participation of non-independent Caribbean countries in the United Nations: a method for self-determination, in A. G. Ramos and A. I. Rivera (Eds), Islands at the Crossroads: Politics in the Non-Independent Caribbean, pp. 136-159 (Kingston: Ian Randle Publishers).

Dee, W. (2001) In Pursuit of Sovereignty: A Historical Documentation of Nevis' Secession Odyssey (St Joseph, Barbados: Cranlake Publishing).

Duchacek, I. D. (1986) The Territorial Dimension of Politics Within, Among and Across Nations (London: Westview Press).

Duverger, M. (1959) Political Parties (New York: John Wiley).

Farran, C. D'Olivier (1960) The position of diminutive states in international law, in E. Brüel et al. (Eds), Internationalrechtliche und Staatsrechtliche Abhandlungen-Fetschrift für Walter Schätzel zu Seinem Geburtstag, pp. 131-147 (Dusselfdorf: Hermes).

Government of the Cook Islands (2005) Cook Islands Diplomatic and Consular Corps, at www.cookislands.de/index.php? page $=1074121959 \& \mathrm{f}=18 \mathrm{j}=1074121959$

Government of the Faeroes (1999) Huitabok: The White Book (Torshavn: Foroya Landsstyri).

Government of New Zealand (n. d.) Cook Islands, Political, Economic and Social Relationship, Country Paper: Pacific Division, March 2006, at www.mfat.govt.nz/foreign/regions/pacific/ country/cookislandspaper.html

Granatstein, J. L. and Hillmer, N. (1991) For Better or Worse: Canada and the United States to the 1990s (Toronto: Copp, Clark, Pitman).

Gröndal, B. (1974) Iceland: From Neutrality to NATO Membership (Oslo: Universitetforloget).

Gunter, M. (1974) Liechtenstein and the League of Nations: a precedent for the United Nations, American Journal of International Law, LXVIII (July), pp. 496-501.

Hudson, M. O. (1935) The members of the League of Nations, British Yearbook of International Law, XVI, pp. 130-152.

Isfeld, S. (2006) Counsellor and Representative of the Faeroe Islands in London, in personal correspondence with the author, 22 January. 
Jansson, C. (2002) Åland's prospects for development in the European Union, in H. Jansson and J. Salminen (Eds), The Second Åland Islands Question: Autonomy or Independence?, pp. 201-212 (Mariehamn: Julius Sundbloms Minnesstiftelse).

Keating, M. (1996) Nations Against the State (London: Macmillan).

Keating, M. (1999) Regions and international affairs: motives, opportunities and strategies, in F. Aldecoa and M. Keating (Eds), Paradiplomacy in Action: The Foreign Relations of Subnational Governments, pp. 1-16 (Portland, OR: Frank Cass).

Knight, D. B. (1982) Identity and territory: geographical perspectives on nationalism and regionalism, Annals of the Association of American Geographers, LXXII, pp. 514-531.

Larsen, F. B. (1992) The quiet life of a revolution: Greenlandic home rule, 1979-92, Inuit Studies, XVI(1-2), pp. 199-226.

League of Nations (1920) Report of the Second Sub-Committee to the Fifth Committee, Records of the First Assembly, Plenary Meetings, Geneva: Switzerland.

Lubin, M. (2003/04) Perforated sovereignties in the Americas: the Canada-US borders and the international outreach activities of Québec, London Journal of Canadian Studies, XIX, pp. $19-40$.

Marks, G., Haesly, R. and Mbaye, H. A. D. (2002) What do subnational offices think they are doing in Brussels?, Regional and Federal Studies, XII(3), pp. 1-23.

Mørkøre, J. (1997) The Faeroese home rule model: theory and reality, in L. Lyck (Ed.), Constitutional and Economic Space of the Small Nordic Jurisdictions, pp. 162-191 (Stockholm: NordREFO).

Motzfeldt, J. (1997) Home rule in Greenland, in L. Lyck (Ed.), Constitutional and Economic Space of the Small Nordic Jurisdictions, pp. 192-195 (Stockholm: NordREFO).

Myntti, K. (2002) The Åland model: background and special characteristics, in H. Jansson and J. Salminen (Eds), The Second Åland Islands Question: Autonomy or Independence, pp. 107124 (Mariehamn: Julius Sundbloms Minnesstiftelse).

Olafsson, A. (2000) Constitutionalism and economics in the Faeroes, in G. Baldacchino and D. Milne (Eds), Lessons from the Political Economy of Small Islands: The Resourcefulness of Jurisdiction, pp. 121-140 (London: Macmillan).

Premdas, R. R. (1998) Secession and Self-Determination in the Caribbean: Nevis and Tobago (St Augustine: School of Continuing Studies, University of the West Indies).

Raton, P. (1970) Liechtenstein: History and Institutions of the Principality (Vaduz: Liechtenstein-Verlag).

Rennie, D. (2006) Tiny island that's ready to stop Europe in its tracks, Daily Telegraph, 15 February.

Royal Gazette (Bermuda) (2005) Independence position, 16 November, at www.theroyalgazette.com/

Rushby, K. (2001) Another day, another coup, Guardian, 1 October.

Scarpulla, C. (2002) The special status of Aland in Finland and the European Union, in H. Jansson and J. Salminen (Eds), The Second Aland Islands Question: Autonomy or Independence?, pp. 125-146 (Mariehamn: Julius Sundbloms Minnesstiftelse).

Schei, L. K. and Moberg, G. (1991) The Faeroe Islands (London: John Murray).

Séguin, R. (2006) Dawn of a new era?, Globe and Mail (Toronto), 9 March. 